Куликова А.Х., Козлов А.В., Уромова И.П.

стение: автореф. дис. ... д-ра биол. наук. Пущино, 2008.34 c.

13. Pirzad A., Mohammadzadeh S. Zeolite use efficiency variation under water deficit stress in grass pea and lentil // Журнал Сибирского федерального университета. Серия: Биология. 2016. № 9 (3). С. 291303.

14. Белоусов В.С. Применение цеолитсодержащей породы как сорбента аммиака и пестицидов из водных сред // Агрохимия. 2005. № 8. С. 65-69.

15. Козлов А.В., Уромова И.П., Фролов Е.А., Мозолева К.Ю. Физиологическое значение кремния в онтогенезе культурных растений и при их защите от фитопатогенов // Международный студенческий научный вестник. 2015. № 1. С. 39.

16. Козлов А.В., Куликова А.Х. Влияние высококремнистых пород на структуру, численность и ферментативную активность целлюлозосапротрофного микробного пула дерново-подзолистой почвы в условиях выращивания озимой пшеницы и картофеля // Вестник Ульяновской государственной сельскохозяйственной академии. 2016. № 1 (33). С. 56-65.
17. Козлов А.В. Экологическая оценка влияния диатомита на фитоценоз и состояние почвеннобиотического комплекса светло-серой лесной легкосуглинистой почвы: дис. ... канд. биол. наук. Н. Новгород, 2013. $182 \mathrm{c.}$

18. Дистанов У.Г. Минеральное сырье. Опалкристобалитовые породы: справочник. М.: Геоинформарк, 1998. 27 с.

19. Рабочая классификация почв Горьковской области / под ред. Б.А. Никитина. Горький: ГСХИ, $1990.87 \mathrm{c}$.

20. ГОСТ 26483-85. Почвы. Приготовление солевой вытяжки и определение ее $\mathrm{pH}$ по методу ЦИНАО. М.: Изд-во стандартов, 1986. 6 с.

21. Доспехов Б.А. Методика полевого опыта (с основами статистической обработки результатов исследований). М.: ИД Альянс, 2011. 352 с.

22. Добровольский Г.В., Никитин Е.Д. Экология почв. М.: Издательство МГУ, 2012. 412 с.

23. Зайдельман Ф.Р. Генезис и экологические основы мелиорации почв и ландшафтов. М.: Издательство КДУ, 2009. 720 с.

\title{
ASSESSMENT OF RELEVANT AND EXCHANGE ACIDITY OF CESPITOSE-PODSOLIC SANDY LOAMY SOIL WHEN THE HOTYNETSKY FIELD ZEOLITE IS USED
}

\author{
Kulikova Alevtina Hristoforovna, doctor of agricultural sciences, \\ head of Soil Science, Agrochemistry and Agroecology Department \\ Ulyanovsk State Agrarian University named after P.A. Stolypin (Ulyanovsk, Russian Federation) \\ Kozlov Andrey Vladimirovich, candidate of biological sciences, \\ associate professor of Ecological Education and Rational Environmental Management Department \\ Uromova Irina Pavlovna, doctor of agricultural sciences, \\ professor of Biology, Chemistry and Biological and Chemical Education Department \\ Minin Nizhny Novgorod State Pedagogical University (Nizhny Novgorod, Russian Federation)
}

\begin{abstract}
The following paper considers influence extent of zeolite breed of the Hotynetsky field on indicators of relevant and exchange acidity of the cespitose-podsolic sandy loamy soil in the Nizhny Novgorod Region. A threeyear experiment, representing microfield experiment, was started in 2014 in the Borsky District «Elitkhoz». Zeolite was brought in the plough-layer once in high doses - 3, 6 and 12 t/hectare. During the research (2015-2017) on allotments the main crops of the region were grown up. The acidity of the soil was estimated on $\mathrm{pH}$ indicators, defined from water and salt extracts which were selected during the autumn period after cultural plants harvesting. As a result of the conducted researches positive action of all doses of the studied zeolite on indicators of the acid and main mode of the cespitose-podsolic soil was established. The essential effect was traced already at the minimum dose of material: $12,0 \%$ increase of $\mathrm{pH}_{\text {water }}$ indicator and 6,3\% increase of $\mathrm{pH}_{\text {salt }}$ indicator on average during the research time. Application of $6 \mathrm{t} /$ hectare of zeolite breed in the greatest measure promoted reduction of the relevant acidity of the soil by $20 \%$, exchange acidity - for $13 \%$ and also for $60 \%$ - to increase in an ionic exchanging of the soil solution system with preservation of the action force during the research time.

Keywords: zeolite breed of Hotynetsky field; cespitose-podsolic sandy loamy soil; relevant acidity; exchange acidity; ionic exchanging; soil solution system; acid and main state; soil absorbing complex; exchange compounds of calcium and magnesium.
\end{abstract}

УДК 591.9: 598.2

Статья поступила в редакцию 09.04.2018

\section{СТРУКТУРА И ФАКТОРЫ ФОРМИРОВАНИЯ РАЗНООБРАЗИЯ ПТИЦ ЛЕСНЫХ МЕСТООБИТАНИЙ РОССИЙСКОГО ПРИИШИМЬЯ}

Левых Алёна Юрьевна, кандидат биологических наук, доцент кафедры биологии, географии и методики их преподавания

Болдырев Степан Леонидович, аспирант кафедры биологии, географии и методики их преподавания Ииимский педагогический институт имени П.П. Ершова (филиал)

Тюменского государственного университета (г. Ииим, Тюменская область, Российская Федераџия)

Аннотащия. На основе материалов полевых учётов птиц, проведённых в сезоны 2014-2016 гг. на 28 постоянных маршрутах в лесных местообитаниях Российского Приишимья, исследована связь между отдель- 
ными параметрами местообитаний (площадь леса на маршруте, средний возраст леса, сомкнутость крон, состояние крон, вид антропогенного воздействия, стадия растительной сукцессии, заболоченность (увлажнение) леса), обилием птиц, индексами видового разнообразия Шеннона и Симпсона лесных орнитоценозов. Методом однофакторного дисперсионного анализа с помощью непараметрического критерия КраскелаУоллиса установлено статистически значимое влияние антропогенного воздействия на индекс разнообразия Шеннона, а также значимое влияние стадии растительной сукцессии на индекс видового разнообразия Шеннона и обилие птиц. Показано, что максимальным значением индекса разнообразия Шеннона характеризуются орнитоценозы рекреационных лесов, близким к максимальному - лесов, в которых осуществляется выпас скота. В ходе растительной сукцессии наблюдается первоначально незначительное увеличение суммарного обилия птиц, затем его значимое понижение, а также резкое уменьшение индекса разнообразия Шеннона. Полученные результаты показывают, что антропогенное воздействие в виде выпаса скота и рекреации обусловливает увеличение гетерогенности лесных местообитаний и тем самым способствует увеличению видового разнообразия птиц.

Ключевые слова: птицы; орнитофауна; лесные орнитоценозы; лесные экосистемы; местообитание; обилие; биологическое разнообразие; видовое разнообразие; экологическая структура; антропогенное воздействие; растительная сукцессия; юг Западной Сибири; индексы разнообразия.

\section{Введение}

В XX веке природная среда Сибири претерпела кардинальные изменения, в значительной мере в результате хозяйственной деятельности, а также климатических трендов [1, с. 66-67]. Основными факторами антропогенной трансформации лесных экосистем явились производственная деятельность человека, в том числе переход сельского хозяйства на индустриальную основу, урбанизация, интенсивное лесопользование и пожары [2, с. 285; 3, р. 3730; 4, p. 3729-3730; 5, p. 2544; 6, р. 426]. Помимо прямого влияния указанных факторов в ряде работ показано их опосредованное и интегральное воздействие на экосистемы [3, р. 3730; 8, с. 403-404, 409; 9, с. 420]. В ходе комплексной оценки биологического разнообразия на территории зернового пояса Западной Сибири в контексте климатических изменений установлена значимая обратная связь между прекращением ведения сельского хозяйства и видовым разнообразием растений, насекомых, птиц [4, р. 3729$3730 ; 5$, p. 2544]. Подобная тенденция, хотя и без учёта климатических изменений, установлена и для мелких млекопитающих [7, с. 21-22]. Тем не менее до сих пор недостаточно изучено влияние отдельных факторов местообитаний на структуру животного населения [9, с. 420]. Особенно мало исследованными в этом отношении являются лесные экосистемы лесостепной зоны Западной Сибири [10, с. 27].

Цель исследования: изучение структуры и факторов формирования разнообразия птиц лесных местообитаний Российского Пришимья.

\section{Материалы и методы исследований}

Исследования проводили в полевые сезоны 2014 2017 гг. на территории семи районов юга Тюменской области (Абатский, Бердюжский, Викуловский, Ишимский, Казанский, Сладковский, Сорокинский р-ны) и одного района (Усть-Ишимский) Омской области, расположенных в водосборных и водораздельных территориях реки Ишим и его притоков. Наблюдение проводили методом маршрутных учётов без ограничения ширины трансекта [11, с. 66-75] в модификации С.Н. Гашева [12, с. 58-60]. В каждом из изучаемых местообитаний закладывали постоянный маршрут длиной 3,1-4 км, учёты на котором проводились одним учётчиком не менее трёх раз в каждый из сезонов (весенне-летний - начало апреля - середина июля; летне-осенний - середина июля конец октября). Для каждого местообитания составляли геоботаническое описание, в котором отмечали возраст древостоя, сомкнутость крон, состояние крон, состав подлеска, степень увлажнения местообитания [13, с. 39-46; 14, с. 7]. Местообитания классифицировали по приурочености к определённой группе формаций растительности - выделили 6 типов и 4 подтипа (табл. 1). Всего заложили 28 маршрутов в различных местообитаниях.

По результатам всех учётов на каждом маршруте рассчитали средние арифметические значения показателей обилия (экз./км²), индексов видового разнообразия Шеннона (H) и Симпсона (D) [16, с. 126146 ; 17 , c. $981-01 ; 18$, p. $25-35 ; 19$, p. 6-9, 21-27; 20, c. 104-124].

Для изучения факторов, обусловливающих пространственно-биотопическое распределение птиц, с помощью статистического пакета программ $\mathrm{R}[18$, p. 25-35; 21, c. 68-83] провели однофакторный непараметрический дисперсионный анализ по восьми факторам (площадь леса на маршруте, средний возраст леса, сомкнутость крон, состояние крон (жизненность), вид антропогенного воздействия, стадия растительной сукцессии, заболоченность (увлажнение) леса). Предварительно каждый фактор ранжировали по балльной шкале (табл. 1). Оценку влияния каждого фактора на показатели обилия и видового разнообразия производили с помощью рангового критерия Краскела-Уоллиса (Н) [18, р. 25-35; 21, с. $68-83 ; 22$, с. 52-56]. Межвыборочные статистические сравнения проводили с помощью t-критерия Стьюдента [22, с. 96].

\section{Результаты исследования и их обсуждение}

Максимальная суммарное обилие птиц при средних показателях видового разнообразия отмечено в берёзово-осиновом лесу с перелесками, характеризующемся хорошим состоянием крон, с сомкнутостью крон 40\%, развитым травяно-кустарничковым ярусом с присутствием высоких трав, достаточным уровнем увлажнения, отсутствием следов пожара, использующемся для сбора дикоросов, находящемся на заключительной стадии растительной сукцессии (табл. 2). 
Левых А.Ю., Болдырев С.Л. 03.02.00 - общая биология Структура и факторы формирования разнообразия птиц лесных местообитаний..

Таблица 1 - Параметры местообитаний и градация факторов пространственно-биотопического распределения птиц в лесных местообитаниях Российского Приишимья

\begin{tabular}{|c|c|c|c|c|c|c|c|c|c|c|c|}
\hline № & Широта & Долгота & I & II & III & IV & $\mathrm{V}$ & VI & VII & VIII & IX \\
\hline 1 & 56,011123 & 69,503205 & СЛ & 4 & 3 & 5 & 4 & 4 & 4 & 5 & 5 \\
\hline 2 & 55,650916 & 68,711258 & БК & 3 & 2 & 2 & 2 & 3 & 3 & 5 & 3 \\
\hline 3 & 55,872870 & 69,504455 & БК1 & 4 & 3 & 2 & 3 & 4 & 5 & 5 & 5 \\
\hline 4 & 55,944956 & 69,469139 & БОЛ & 4 & 4 & 3 & 4 & 4 & 5 & 5 & 4 \\
\hline 5 & 56,297945 & 69,506831 & БОК & 3 & 3 & 4 & 4 & 3 & 3 & 3 & 3 \\
\hline 6 & 56,045055 & 69,829182 & БОЛ & 4 & 3 & 3 & 3 & 3 & 3 & 4 & 2 \\
\hline 7 & 55,904302 & 69,178012 & ОБЛ1 & 3 & 2 & 2 & 3 & 3 & 3 & 3 & 1 \\
\hline 8 & 55,460899 & 69,613083 & БОЛ & 2 & 4 & 2 & 3 & 4 & 2 & 5 & 4 \\
\hline 9 & 55,482713 & 69,553920 & БОЛ & 3 & 4 & 3 & 4 & 4 & 4 & 4 & 2 \\
\hline 10 & 55,585920 & 70,490855 & БОЛ & 3 & 2 & 2 & 3 & 4 & 3 & 4 & 5 \\
\hline 11 & 55,585920 & 70,331618 & БК2 & 3 & 2 & 2 & 2 & 4 & 3 & 3 & 5 \\
\hline 12 & 55,999537 & 68,834577 & БОЛ 2 & 4 & 3 & 3 & 4 & 4 & 4 & 5 & 2 \\
\hline 13 & 56,165587 & 68,859584 & БОК & 4 & 5 & 4 & 4 & 3 & 4 & 4 & 3 \\
\hline 14 & 55,585920 & 70,331618 & БОК & 3 & 3 & 2 & 4 & 3 & 4 & 3 & 4 \\
\hline 15 & 56,384198 & 69,062616 & БОК & 3 & 4 & 3 & 3 & 4 & 4 & 4 & 3 \\
\hline 16 & 56,040499 & 70,070549 & БОК & 4 & 3 & 3 & 4 & 4 & 3 & 4 & 4 \\
\hline 17 & 56,006452 & 70,377551 & БК & 3 & 4 & 3 & 3 & 4 & 4 & 4 & 4 \\
\hline 18 & 56,236784 & 70,546572 & БК1 & 3 & 3 & 2 & 3 & 3 & 4 & 4 & 5 \\
\hline 19 & 56,392582 & 70,463828 & БК3 & 3 & 3 & 2 & 3 & 4 & 4 & 5 & 4 \\
\hline 20 & 56,464878 & 69,962960 & ОБЛ & 4 & 4 & 4 & 3 & 4 & 3 & 5 & 1 \\
\hline 21 & 56,788340 & 70,256040 & БОЛ & 4 & 5 & 4 & 4 & 4 & 2 & 5 & 2 \\
\hline 22 & 56,752209 & 69,522162 & БОЛ & 5 & 3 & 3 & 4 & 3 & 3 & 4 & 1 \\
\hline 23 & 56,667314 & 69,700160 & БОЛ & 4 & 4 & 4 & 3 & 3 & 2 & 4 & 2 \\
\hline 24 & 56,558245 & 70,321645 & БОК & 4 & 3 & 3 & 4 & 3 & 2 & 4 & 1 \\
\hline 25 & 56,834001 & 71,090886 & БОК & 5 & 4 & 3 & 3 & 4 & 2 & 5 & 2 \\
\hline 26 & 56,978163 & 70,699339 & СЛ & 5 & 2 & 3 & 2 & 2 & 3 & 4 & 3 \\
\hline 27 & 57,051520 & 70,638550 & БОЛ & 4 & 3 & 4 & 3 & 4 & 2 & 5 & 3 \\
\hline 28 & 57,037540 & 70,269827 & СЛ & 5 & 2 & 3 & 3 & 4 & 4 & 5 & 4 \\
\hline
\end{tabular}

Примечание. I - тип местообитания: СЛ - сосновые леса, $Б K-$ берёзовые колки, БК1 - берёзовые колки на склонах, БОЛ - берёзово-осиновые леса, БОК - берёзово-осиновые колки, ОБЛ1 - заболоченные осиновоберёзовые леса, БК2 - разреженные берёзовые колки, БОЛ2 - берёзово-осиновые леса с перелесками, БК 3 берёзовые колки на возвышенностях, ОБЛ - осиново-берёзовые леса, ПЛ - пойменный лес. II - антропогенное воздействие: 1 - вырубки, 2 - выпас скота, 3 - рекреация, 4 - сбор дикоросов, 5 - отсутствие видимого воздействия. $I I I$ - доля площади лесных участков в \% от площади учётной полосы: 1 - 25-30, 2 - 30-40, 3 - 40-60, 4 - 60-80, 5 - 90 и более \%. IV - возраст древостоя: 1 - 15-20 лет, 2 - 2030 лет, 3 - 30-40 лет, 4 - 50-60 лет, 5 - 70 и более лет. $V$ - сомкнутость крон в \%: $1-40-50,2-50-60,3-60-$ 70,4 - 70 и более \%. VI - состояние крон: 1 - угнетённое, 2 - слабое, 3 - умеренное, 4 - хорошее. VII - состав подлеска (по наличию индикаторных групп растений): 1 - мхи-лишайники, 2 - травянистые растения, 3 - травянистые растения и кустарнички, 4 - кустарнички, полукустарники, высокие травянистые растения (зонтичные, лабазник вязолистный), 5 - кустарники. VIII - стадия растительной сукцессии (по наличию индикаторных групп растений): 1 - рудеральные травы, 2 - кустарники и поросль берёзы, 3 - молодые березняки, 4 - спелые березняки, сосняки, 5 - зрелый лес без следов пожара. IX - степень заболоченности (по влажности почвы): 1 - заболоченные леса, 2 - влажные леса, 3 - сырые леса, 4 - сыроватые леса, 5 - сухие леса.

При попарном сравнении разных типов местообитаний установлено, что обилие птиц в берёзовоосиновом лесу с перелесками (маршрут № 12) статистически значимо выше, чем в берёзово-осиновых лесах без перелесков $(\mathrm{t}=4,01$, при $\mathrm{p} \leq 0,001)$, использующихся для выпаса скота, в рекреационных целях, для сбора дикоросов, и значимо выше, чем в берёзовых колках разного типа (БОЛ2-БК $-\mathrm{t}=4,42$, при $\mathrm{p} \leq 0,001$; БОЛ2-БК $3-\mathrm{t}=3,61$, при $\mathrm{p} \leq 0,01$; БОЛБК $1-t=2,19$, при $\mathrm{p} \leq 0,05$; БОЛ2-БК $2-\mathrm{t}=2,36$, при $\mathrm{p} \leq 0,05)$, использующихся в рекреационных целях или для сбора дикоросов. Наибольший вклад в суммарное обилие птиц берёзово-осинового леса с перелесками вносят: дуплогнёздники - Cyanistes cyanus Pallas, 1770 (4,57 экз./км²; 11,23\%); Cyanistes caeruleus L., 1758 (2,57 экз./км²; 6,3\%); наземногнёздники и низкогнёздники - Phylloscopus trochilus L., 1758
(4,29 экз./Км²; 10,54\%); Phylloscopus trochiloides Sundevall, 1837 (3,43 экз./км²; 8,43\%); Luscinia luscinia L., 1758 (2,57 экз./Км²; 6,3\%); Emberiza citronella L., 1758 (2 экз./км²; 4,9\%); Luscinia svecica L., 1758 (2 экз./Км²; 4,91\%); Phylloscopus collybita Vieillot, 1817 (2 экз./км²; 4,9\%); низко и среднегнездящиеся птицы с открытыми гнёздами - Acrocephalus dumetorum Blyth, 1849 (1,71 экз./км²; 4,2\%); Turdus pilaris L., 1758 (1,34 экз./км²; 3,29\%).

Максимальные значения индекса разнообразия Шеннона, придающего больший вес малочисленным видам, отмечены в орнитоценозе берёзово-осинового колка (маршрут № 25), характеризующегося значительной площадью, хорошим состоянием крон, развитым травянистым ярусом, высокой влажностью и отсутствием следов хозяйственной деятельности (табл. 1, 2). 
таблица 2 - Суммарное обилие и индексы видового разнообразия орнитоценозов в разных типах местообитаний

\begin{tabular}{|c|c|c|c|c|c|}
\hline $\begin{array}{c}\text { № } \\
\text { маршрута }\end{array}$ & $\begin{array}{l}\text { Тип место- } \\
\text { обитаний }\end{array}$ & $\begin{array}{c}\text { Число } \\
\text { видов птиц }\end{array}$ & $\begin{array}{l}\text { Суммарное оби- } \\
\text { лие птиц, экз./км² }\end{array}$ & $\begin{array}{c}\text { Индекс видового разно- } \\
\text { образия Шеннона }(\mathrm{H})\end{array}$ & $\begin{array}{c}\text { Индекс видового разно- } \\
\text { образия Симпсона (D) }\end{array}$ \\
\hline 1 & СЛ & 24 & $320,4 \pm 21,3$ & $3,45 \pm 0,23$ & $0,94 \pm 0,06$ \\
\hline 2 & БК & 18 & $247,71 \pm 11,5$ & $2,92 \pm 0,2$ & $0,95 \pm 0,17$ \\
\hline 3 & БК1 & 19 & $454,33 \pm 28,15$ & $3,33 \pm 0,52$ & $0,94 \pm 0,12$ \\
\hline 4 & БОЛ & 14 & $195,34 \pm 13,64$ & $3,60 \pm 0,22$ & $0,8 \pm 0,1$ \\
\hline 5 & БОК & 20 & $330,63 \pm 6,13$ & $7,24 \pm 0,21$ & $0,53 \pm 0,28$ \\
\hline 6 & БОЛ & 24 & $330,9 \pm 6,8$ & $3,31 \pm 0,32$ & $0,96 \pm 0,1$ \\
\hline 7 & ОБЛ1 & 22 & $242,34 \pm 10,09$ & $5,55 \pm 0,36$ & $0,78 \pm 0,07$ \\
\hline 8 & БОЛ & 20 & $256,6 \pm 10,64$ & $4,21 \pm 0,16$ & $0,86 \pm 0,14$ \\
\hline 9 & БОЛ & 24 & $403,13 \pm 25,6$ & $4,34 \pm 0,19$ & $0,91 \pm 0,1$ \\
\hline 10 & БОЛ & 13 & $140,27 \pm 11,73$ & $2,86 \pm 0,25$ & $0,85 \pm 0,16$ \\
\hline 11 & БК2 & 15 & $222,37 \pm 10,03$ & $5,89 \pm 0,12$ & $2,41 \pm 0,19$ \\
\hline 12 & БОЛ2 & 22 & $474,9 \pm 27,11$ & $3,24 \pm 0,25$ & $0,83 \pm 0,12$ \\
\hline 13 & БОК & 24 & $331,88 \pm 9,45$ & $3,12 \pm 0,16$ & $0,97 \pm 0,13$ \\
\hline 14 & БОК & 28 & $450,44 \pm 12,9$ & $3,76 \pm 0,09$ & $0,96 \pm 0,12$ \\
\hline 15 & БОК & 14 & $156,89 \pm 12,4$ & $5,34 \pm 0,19$ & $0,29 \pm 0,12$ \\
\hline 16 & БОК & 19 & $289,43 \pm 13,3$ & $2,56 \pm 0,21$ & $0,97 \pm 0,9$ \\
\hline 17 & БК & 11 & $128,37 \pm 9,51$ & $3,51 \pm 0,19$ & $0,32 \pm 0,07$ \\
\hline 18 & БК1 & 19 & $204,34 \pm 15,84$ & $6,13 \pm 0,2$ & $0,42 \pm 0,06$ \\
\hline 19 & БК 3 & 10 & $92,7 \pm 10,09$ & $3,63 \pm 0,16$ & $0,67 \pm 0,16$ \\
\hline 20 & ОБЛ & 14 & $144,06 \pm 12,98$ & $2,41 \pm 0,25$ & $0,96 \pm 0,06$ \\
\hline 21 & БОЛ & 12 & $208,36 \pm 10,35$ & $1,97 \pm 0,19$ & $0,93 \pm 0,17$ \\
\hline 22 & БОЛ & 16 & $187,48 \pm 11,18$ & $5,90 \pm 1,04$ & $1,04 \pm 0,12$ \\
\hline 23 & БОЛ & 18 & $221,91 \pm 8,9$ & $4,7 \pm 0,84$ & $0,84 \pm 0,03$ \\
\hline 24 & БОК & 17 & $175,83 \pm 10,92$ & $7,01 \pm 3,7$ & $3,57 \pm 0,16$ \\
\hline 25 & БОК & 26 & $224,8 \pm 12,08$ & $11,35 \pm 1,7$ & $1,75 \pm 0,03$ \\
\hline 26 & СЛ & 22 & $323,57 \pm 10,06$ & $3,91 \pm 0,8$ & $0,89 \pm 0,19$ \\
\hline 27 & БОЛ & 20 & $366,23 \pm 15,84$ & $3,43 \pm 0,93$ & $0,93 \pm 0,07$ \\
\hline 28 & СЛ & 30 & $468,02 \pm 14,02$ & $4,76 \pm 0,91$ & $0,91 \pm 0,06$ \\
\hline
\end{tabular}

Высокие значения индекса разнообразия Шеннона отмечены также в орнитоценозах молодых и спелых, соответственно, сырых и заболоченных берёзово-осиновых колков с развитым травянистым или травяно-кустарничковым ярусом, использующихся лишь в рекреационных целях или для сбора дикоросов (маршруты № 5 и 24). Различия по индексу разнообразия Шеннона между орнитоценозами отмеченных берёзово-осиновых колков и других типов местообитаний статистически значимы (БОК-БОЛ $\mathrm{t}=14,80$, при $\mathrm{p} \leq 0,001 ;$ БОК-БОЛ $2-\mathrm{t}=3,54$, при $\mathrm{p} \leq 0,001 ;$ БОК-БК $-\mathrm{t}=6,27$, при $\mathrm{p} \leq 0,001$; БОК-БК3 $-\mathrm{t}=3,10$, при $\mathrm{p} \leq 0,01$; БОК-ОБЛ $-\mathrm{t}=4,29$, при $\mathrm{p} \leq 0,001$; БОК-СЛ $-\mathrm{t}=6,30$, при $\mathrm{p} \leq 0,001)$. Самыми малочисленными видами берёзово-осиновых колков, внёсшими наибольший вклад в индекс разнообразия Шеннона, явились на маршруте № 5 - открытогнездящиеся виды: наземногнёздник Anthus campestris L., 1758 (1,71 экз./км²; 0,99\%); высокогнездящийся на опушке леса вид Carduelis carduelis L., 1758 (1,71 экз./км²; 0,99\%); среднегнездящийся вид Carpodacus erythrinus Pallas, 1770 (1,71 экз./Км²; 0,99\%); на маршруте № 24 - открытогнездящиеся виды: среднегнездящийся вид Pyrrhula pyrrhula L., 1758 $(0,86$ экз./км²; $0,51 \%)$; наземногнёздники Phylloscopus collybita $(0,57$ экз./Км²; $0,34 \%)$; Tetrastes bonasia L., 1758 (0,29 экз./км²; 0,17\%); на маршруте № 25 открытогнездящиеся виды: низкогнездящийся вид Acrocephalus dumetorum $(0,86$ экз./км²; 0,54\%); среднегнездящийся вид Chloris chloris L., 1758 $\left(0,86\right.$ экз./Км $\left.{ }^{2} ; 0,54 \%\right)$.
Наибольшее значение индекса видового разнообразия Симпсона, придающего больший вес обычным, многочисленным, видам отмечено в заболоченном берёзово-осиновом колке, характеризующемся значительной площадью, умеренным состоянием крон, развитостью травянистого яруса, использующемся только для сбора дикоросов (маршрут № 24) (табл. 2). Многочисленными («обычными») видами в этом местообитании явились: дуплогнёздники Parus montanus Conrad, 1827 (52,57 экз./км²; 31,6\%); Cyanistes caeruleus $(10,86$ экз./Км²; 6,52\%); Cyanistes cyanus $(10,86$ экз./км² $; 6,52 \%)$ и наземногнёздники $A n$ thus trivialis L., 1758 (14 экз./Км²; 8,41\%); Emberiza citrinella (11,71 экз./км²; 7,04\%). Высоким индексом разнообразия Симпсона характеризуется орнитоценоз разреженного хорошо увлажнённого берёзового колка с хорошим состоянием крон, развитым травянокустарниковым ярусом и рекреационным использованием (маршрут № 11) (табл. 3). «Обычные» в берёзовом колке виды: дуплогнёздники Parus montanus (75,83 экз./км²; 27,6\%); Parus major L., 1758 (35,83 экз./км²; 13,07\%); открытогнездящиеся виды - средне и высокогнездящийся вид Fringilla coelebs L., 1758 (29,58 экз./км²; 10,7\%); низкогнездящийся вид Acrocephalus dumetorum (18,75 экз./км²; 6,84\%); высокогнездящийся вид Carduelis carduelis (16,25 экз./ км²; 5,92\%); наземногнёздник Phylloscopus trochilus L., 1758 (20,08 экз./км²; 7,3\%). Отмеченные более высокие значения индекса разнообразия Симпсона в орнитоценозах заболоченного берёзово-осинового колка и разреженного берёзового колка подтвержде- 
ны статистически (БОК-БОЛ $-\mathrm{t}=31,55$, при $\mathrm{p} \leq 0,001$; БОК-БОЛ $2-\mathrm{t}=5,27$, при $\mathrm{p} \leq 0,001$; БОКБК $-\mathrm{t}=16,65$, при $\mathrm{p} \leq 0,001 ;$ БОК-БК $3-\mathrm{t}=8,42$, при $\mathrm{p} \leq 0,001 ;$ БОК-БК $1-\mathrm{t}=15,9$, при $\mathrm{p} \leq 0,001 ;$ БОКОБЛ $1-\mathrm{t}=8,68$, при $\mathrm{p} \leq 0,001$; БОК-ОБЛ $-\mathrm{t}=4,93$, при $\mathrm{p} \leq 0,001$; БОК-БК $2-\mathrm{t}=8,69$, при $\mathrm{p} \leq 0,001$; БОК-СЛ - $\mathrm{t}=10,22$, при $\mathrm{p} \leq 0,001 ;$ БК2-БОЛ $\mathrm{t}=17,61$, при $\mathrm{p} \leq 0,001$; БК2-БОЛ $2-\mathrm{t}=4,04$, при $\mathrm{p} \leq 0,001$; БК2-БК $3-\mathrm{t}=4,71$, при $\mathrm{p} \leq 0,001$; БК2-БК1 $-\mathrm{t}=7,95$, при $\mathrm{p} \leq 0,001$; БК2-ОБЛ $1-\mathrm{t}=4,76$, при $\mathrm{p} \leq 0,001 ;$ БК2-ОБЛ $-\mathrm{t}=3,96$, при $\mathrm{p} \leq 0,001 ;$ БК2-СЛ $-\mathrm{t}=8,21$, при $\mathrm{p} \leq 0,001)$.

таблица 3 - Показатели связи между факторами пространственно-биотопического распределения обилием и индексами видового разнообразия птиц

\begin{tabular}{|l|c|c|c|c|c|c|}
\hline \multirow{2}{*}{\multicolumn{1}{c|}{ Факторы }} & \multicolumn{2}{c|}{ Индекс Симпсона } & \multicolumn{2}{c|}{ Индекс Шеннона } & \multicolumn{2}{c|}{ Обилие в экз./км ${ }^{2}$} \\
\cline { 2 - 7 } & Н-критерий & $\mathrm{k}$ & Н-критерий & $\mathrm{k}$ & Н-критерий & $\mathrm{k}$ \\
\hline $\begin{array}{l}\text { Доля площади лесных участков, } \\
\text { \% от учётной полосы }\end{array}$ & 0,55 & 3 & 1,83 & 3 & 2,28 & 3 \\
\hline Возраст древостоя & 0,76 & 3 & 6,28 & 3 & 0,21 & 3 \\
\hline Сомкнутость крон & 2,90 & 2 & 0,61 & 2 & 0,03 & 2 \\
\hline Состояние крон & 0,86 & 2 & 2,19 & 2 & 3,24 & 2 \\
\hline Антропогенное воздействие & 6,04 & 3 & $12,81 * *$ & 3 & 1,91 & 3 \\
\hline Состав подлеска & 2,41 & 3 & 2,42 & 3 & 0,96 & 3 \\
\hline Стадия растительной сукцессия & 2,77 & 2 & $7,45^{*}$ & 2 & $7,49 *$ & 2 \\
\hline Степень заболоченности & 2,11 & 4 & 5,32 & 4 & 2,96 & 4 \\
\hline
\end{tabular}

Примечание. $H$ - критерий Краскела-Уоллиса, $k$ - число степеней свободы, $p$ - уровень значимости; * - различия достоверны при $p<0,05$; **-различия достоверны при $p<0,01$.

При этом наблюдается прямая связь между антропогенной нагрузкой и индексом разнообразия Шеннона (рис. 1). Максимальным значением индекса
Присутствие в отмеченных орнитоценозах видов с разной гнездовой биологией индицирует наличие разнообразных микробиотопов, в том числе открытых («просветлённых») участков, которые отчасти образуются или сохраняются благодаря рекреационной деятельности человека и выпасу скота.

Проведённый однофакторный дисперсионный анализ выявил статистически значимое влияние антропогенной деятельности на индекс разнообразия Шеннона, а также значимое влияние стадии растительной сукцессии на индекс видового разнообразия Шеннона и обилие птиц (табл. 3 ; рис. 1). разнообразия Шеннона характеризуются орнитоценозы рекреационных лесов, близким к максимальному - лесов, в которых осуществляется выпас скота.

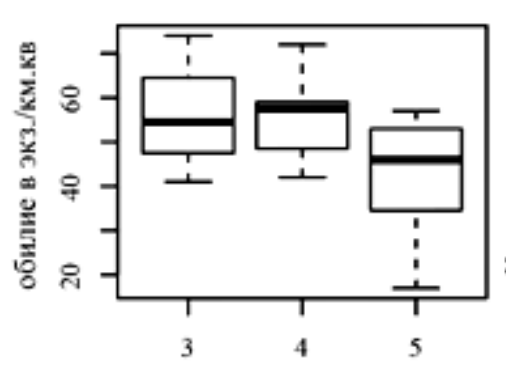

Стадии растительной сукщессии

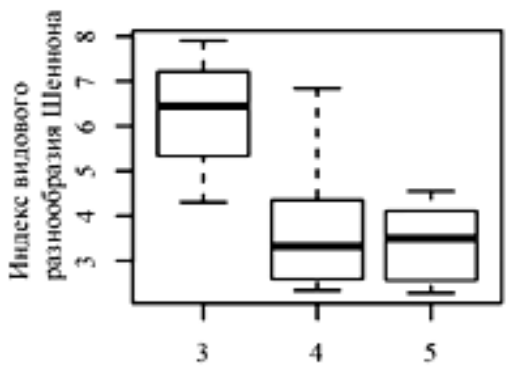

Стадин растительной сукцессий

\section{Рисунок 1 - Оценка влияния антропогенной нагрузки и стадии растительной сукцессии на суммарное обилие птиц и индекс видового разнообразия Шеннона в орнитоценозах лесных местообитаний Приишимья}

В ходе растительной сукцессии наблюдается первоначально незначительное увеличение суммарного обилия птиц, затем его значимое понижение, а также резкое уменьшение индекса разнообразия Шеннона (рис. 1). Полученные результаты показывают, что изменения структуры местообитаний, опосредующиеся через определённые стадии растительной сукцессии, в том числе изменения, обусловленные хозяйственной деятельностью человека, в большей степени сказываются на обилии и распространении малочисленных в лесных сообществах видов птиц, многие из которых являются залётными из смежных местообитаний. Так, в лесах, подверженных выпасу скота, из 64 выявленных видов - 12 «редких» с обилием менее 1 экз./км² и 2 «очень редких» с обилием менее 0,01 экз./км². В лесах, испытывающих рекреационное воздействие, из 60 выявленных видов - 10 «редких» и 4 «очень редких». В лесах, использующихся только для сбора дикоросов, отмечено всего
39 видов, в том числе один «редкий» и ни одного «очень редкого».

\section{Выводы}

Основными факторами, определяющими высокое суммарное обилие и высокие индексы видового разнообразия орнитоценозов, являются площадь лесного массива, достаточная степень увлажнения, высокая жизненность крон, развитость травяно-кустарничкового яруса, разнообразие биотопов, умеренное антропогенное воздействие в виде рекреации и сбора дикоросов.

Степень увлажнения и антропогенное воздействие влияют на разнообразие птиц опосредованно через смену растительных группировок, определяющих структуру местообитания.

Антропогенное воздействие в виде выпаса скота и рекреации обусловливает увеличение гетерогенности лесных местообитаний и тем самым способствует увеличению видового разнообразия птиц. 


\section{Список литературы:}

1. Гашев С.Н., Алешина О.А., Зубань И.А., Лупинос М.Ю., Мардонова Л.Б., Митропольский М.Г., Селюков А.Г., Сорокина Н.В., Столбов В.А., Шаповалов С.И. Фаунистические тренды голоцена на территории Западной Сибири и их причины // Геофизические процессы и биосфера. 2017. Т. 16, № 1. С. 55-74.

2. Соловьёв С.А., Железнова Т.К., Блинов В.Н., Вартапетов Л.Г. Сельскохозяйственное воздействие на население птиц лесостепи и степи юго-западной части Западной Сибири и Северного Казахстана // Птицы и сельское хозяйство: современное состояние, проблемы и перспективы: мат-лы I международ. орнитологич. конф. М., 2016. С. 283-287.

3. Kämpf I., Mathar W., Kuzmin I., Hölzel N., Kiehl K. Post-Soviet Recovery of grassland vegetation on abandoned fields in the forest steppe zone of Western Siberia // Biodiversity and Conservation. 2016. Vol. 25, № 12. P. 2563-2580.

4. Wertebach T-M., Hölzel N., Kämpf I., Yurtaev A., Tupitsin S., Kiehl K., Kamp J., Kleinebecker T. Soil carbon sequestration due to post-Soviet cropland abandonment: estimates from a large-scale soil organic carbon field inventory // Global Change Biology. 2017. Vol. 23, № 9. P. 3729-3741.

5. Brinkert A., Hölzel N., Sidorova TV., Kamp J. Spontaneous steppe restoration on abandoned cropland in Kazakhstan: grazing affects successional pathways // Biodiversity and Conservation. 2016. Vol. 25, № 2. P. 2543-2561.

6. Palpurina S., Wagner V., von Wehrden H., Hajek M., Horsak M., Brinkert A., Hölzel N., Wesche K., Kamp J., Hajkova P., Danihelka J., Lustyk P., Merunkova K., Preislerova Z., Koci M., Kubesova S., Cheresov M., Ermakov N., German D., Gogoleva P., Lashchynsky N., Martynenko V., Chytry M. The relationship between plant species richness and soil $\mathrm{pH}$ vanishes with increasing aridity across Eurasian dry grasslands // Global Ecology and Biogeography. 2017. Vol. 26, № 4. P. 425-434.

7. Сазонова Н.А. Фауна и экология мелких млекопитающих залежных сельскохозяйственных земель юга Тюменской области: автореф. дис. ... канд. биол. наук. Тюмень, 2014. 23 с.

8. Бельский Е.А., Бельская Е.А. Население птиц берёзовых лесов Южного Урала в условиях промышленного загрязнения. Сообщение 1. Реакции видов и сообщества // Сибирский экологический журнал. 2013. № 3. С. 403-411.

9. Бельский Е.А., Бельская Е.А. Население птиц берёзовых лесов Южного Урала в условиях промышленного загрязнения. Сообщение 2. Связь с ха- рактеристикой местообитания // Сибирский экологический журнал. 2013. № 3. С. 413-421.

10. Мордкович В.Г. Западно-Сибирская лесостепь - сгусток биоразнообразия, универсальный биом и резерват грядущих биогеографических реконструкций // Сибирский экологический журнал. 2012. № 1. C. 27-34.

11. Равкин Ю.С. К методике учёта птиц лесных ландшафтов // Природа очагов клещевого энцефалита на Алтае (северо-восточная часть). Новосибирск, 1967. C. 66-75.

12. Гашев С.Н. Практическое применение методики маршрутного учёта птиц с неограниченной шириной учётной полосы // Экологический мониторинг и биоразнообразие. 2014. № 2 (9). С. 58-61.

13. Токарь О.Е. Учебная полевая практика по ботанике с основами фитоценологии: учеб.-метод. пособие для студ. 1 и 2 курсов обучения по специальности «География» с доп. специальностью «Биология». Ишим: ИГПИ им. П.П. Ершова, 2010. 72 с.

14. Мазиров М.А., Шеин Е.В., Корчагин А.А., Шушкевич Н.И., Дембовецкий А.В. Полевые исследования свойств почв: учеб. пособие к полевой практике для студентов, обучающихся по направлению подготовки 021900 - почвоведение. Владимир: Издво ВлГУ, 2012. $72 \mathrm{c}$.

15. Гашев С.Н. Рабочее место орнитолога // Патент России № 2012620405. 2012.

16. Одум Ю. Экология. В 2 т. Т. 2. М.: Мир, 1986. $376 \mathrm{c}$.

17. Шитиков В.К., Розенберг Г.С. Оценка биоразнообразия: попытка формального обобщения // Количественные методы экологии и гидробиологии: сб. науч. тр., посвящённых памяти А.И. Бакалова / отв. ред. чл.-корр. РАН Г.С. Розенберг. Тольятти, 2005. C. $91-129$.

18. McCune B., Grace J.B. Analysis of Ecological Communities. MjM Software Design: Gleneden Beach, Oregon, 2002. 300 p.

19. Magurran A.E. Measuring biological diversity. Blackwell Publishing, Oxford, 2004. 256 p.

20. Макинтош Р.П. Индекс разнообразия и соотношение некоторых концепций разнообразия // Caмарская Лука: проблемы региональной и глобальной экологии. 2013. Т. 22, № 1. С. 104-127.

21. Шипунов А.Б., Балдин Е.М., Волкова П.А., Коробейников А.И., Назарова С.А., Петров С.В., Суфиянов В.Г. Наглядная статистика. Используем R! М.: ДМК Пресс, 2012. 296 c.

22. Ивантер Э.В., Коросов А.В. Элементарная биометрия: учеб. пособие. Петрозаводск: Изд-во ПетрГУ, 2013. 110 с.

\section{STRUCTURE AND FACTORS OF FOREST BIRDS DIVERSITY FORMING IN THE ISHIM RIVER AREA (RUSSIA)}

(C) 2018

Levykh Alyona Yuryevna, candidate of biological sciences, associate professor of Biology, Geography and Teaching Methods Department

Boldyrev Stepan Leonidovich, postgraduate student of Biology, Geography and Teaching Methods Department P.P. Ershov Ishim Pedagogical Institute (branch) of Tyumen State University (Ishim, Tyumen Region, Russian Federation)

Abstract. The paper studies the relationship between specific parameters of habitats (the forest area along the route, the average age of the forest, the closure of the crowns, the condition of the crowns, the type of anthropogenic impact, the stage of vegetative succession, the wetting of the forest), the abundance of birds, Shannon and Simpson's 
indices of the species diversity of forest ornithocenosis. This study is based on the materials of field bird records conducted in the seasons of 2014-2016 on 28 permanent routes in the forest habitats of the Ishim River area (Russia). A statistically significant effect of the anthropogenic impact on the Shannon diversity index and the significant influence of the plant succession stage on Shannon's species diversity index and the abundance of birds have been established by the method of one-way analysis of variance using the nonparametric Kraskel-Wallis's criterion. It is shown that the maximum value of Shannon's index of variety is characteristic for the ornithocenosis of recreational forests; the one close to the maximum is in forests in which grazing is carried out. In the course of plant succession, there is initially an insignificant increase in the total abundance of birds, then a significant decrease in it, as well as a sharp decrease of Shannon's diversity index. The obtained results show that the anthropogenic load in form of cattle grazing and recreation conditions an increase in forest habitats' heterogeneity and thereby contributes to an increase in bird species diversity.

Keywords: birds; avifauna; forest ornithocenosis; forest ecosystems; habitat; abundance; biological diversity; species diversity; ecological structure; anthropogenic impact; plant succession; south of Western Siberia; diversity index.

\section{РАСПРЕДЕЛЕНИЕ ПУЛА ФЛАВОНОЛОВ В НАДЗЕМНОЙ МАССЕ СВЕРБИГИ ВОСТОЧНОЙ (ВUNIAS ORIENTALIS L.) ПРИ ВЫРАЩИВАНИИ НА СЕВЕРЕ} (C) 2018

Михович Жанна Эдуардовна, кандидат биологических наук, научный сотрудник отдела Ботанический сад Пунегов Василий Витальевич, кандидат химических наук, старший научный сотрудник отдела Ботанический сад

Зайнуллина Клавдия Степановна, кандидат биологических наук, старший научный сотрудник отдела Ботанический сад

Рубан Галина Алексеевна, научный сотрудник отдела Ботанический сад Институт биологии Коми научного иентра УрО РАН (2. Сыктывкар, Российская Федеращия)

Аннотаиия. В статье представлены результаты биохимического изучения фитомассы растений свербиги восточной (Bunias orientalis L.), выращенной в условиях среднетаежной подзоны Республики Коми, по срокам ее заготовки. Определена массовая доля флавонолов в период вегетации растений. Установлено, что в фазах массовой бутонизации и массового цветения в ряду стебли-листья-бутоны (или цветки) массовая доля флавонолов возрастает от $0,25 \%$ до $6,06 \%$ и от $0,6 \%$ до $15,43 \%$ соответственно. Показано, что при переходе растений к массовому цветению наблюдается резкое увеличение содержания флавонолов во всех надземных органах растения. Особенно большой рост массовой доли флавонолов был выявлен в цветках свербиги восточной по сравнению с бутонами растений. Безусловный максимум пула флавонолов наблюдается в цветках растения $(15,43 \%)$. Но с учетом того, что массовая доля цветков на генеративном побеге составляет не более $3 \%$, в технологическом плане перспективным источником флавонолов из надземной массы изучаемого растения являются листья и цветки, собранные в фазу цветения, в Республике Коми в третьей декаде июня июле.

Ключевые слова: свербига восточная; семейство Brassicaceae; биохимическое изучение; содержание флавонолов; периоды вегетации растений; распределение по органам растений; цветки; бутоны; стебли; листья; побег; Республика Коми; среднетаежная подзона; выращивание; кормовое растение; лекарственное растение; медоносное растение; пищевое растение; долголетие в культуре.

\section{Введение}

Bunias orientalis L (свербига восточная) - травянистое многолетнее растение семейства Brassicaceae (крестоцветные). Исследования, проведенные в последние годы в различных природно-климатических условиях, показали, что свербига восточная относится к культурам универсального использования: кормового, пищевого, фармацевтического, медоносного и фитомелиоративного $[1$, с. $112 ; 2$, с. 52; 3-6]. Из хозяйственно-ценных признаков данного вида можно выделить такие: зимостойкость, раннее весеннее отрастание, быстрый темп роста и длительный период цветения, резистентность к болезням и вредителям, продуктивное долголетие в культуре, достигающее 10 лет, высокая продуктивность семян и фитомассы, ее кормовая ценность и др. В фитомассе растений содержится от 13 до $36 \%$ сырого протеина, $1,91-3,47 \%$ жира, $8,29-11,98 \%$ золы $[7$, с. $52 ; 8$, с. $252 ; 9$, с. $7 ; 10$, с. 17]. Общая сумма аминокислот в белке фитомассы растений варьирует от 8 до 20 г/100 г сухого вещества в зависимости от фазы развития растений, присутствуют все незаменимые аминокислоты. [10, с. 18]. Фитомасса содержит микроэлементы (бор, железо, медь, молибден, марганец, титан), флавоноиды, органические кислоты, дубильные вещества, сапонины. В незрелых плодах обнаружено горчичное масло, в семенах - жирное масло 10-31\%, в том числе жирные кислоты: линоленовая, линолевая, олеиновая, пальмитиновая, арахиновая, стеариновая, пальмитолеиновая $(52,2 ; 23,6 ; 13,0 ; 4,1$; $3,6 ; 1,740,7 \%)$ соответственно [2, с. $52 ; 11 ; 12 ; 13$, c. $127 ; 14]$. Всесоюзным институтом лекарственных и ароматических растений (ВИЛАР) предлагается использовать свербигу восточную как лекарственное растение, поскольку показано, что под воздействием препаратов на основе растений свербиги увеличива- 